\title{
Effect of Growth Regulators and Chemicals on Germination of Surinam Cherry (Eugenia uniflora L.) Seeds
}

\author{
S. Pavithra ${ }^{1^{*}}$, G.S.K. Swamy ${ }^{2}$, G.J. Suresh ${ }^{3}$, Vishnuvardhana ${ }^{4}$, \\ S.V. Patil ${ }^{5}$ and G.K. Halesh ${ }^{6}$ \\ ${ }^{1}$ Department of Fruit Science, College of Horticulture, Bengaluru, Karnataka, India \\ ${ }^{2}$ Department of Fruit Science, College of Horticulture, Myuru, Karnataka, India \\ ${ }^{3}$ Department of Postharvest Technology, College of Horticulture, Bengaluru, Karnataka, India \\ ${ }^{4}$ Department of Vegetable Science, College of Horticulture Bengaluru, Karnataka, India \\ ${ }^{5}$ Department of Agronomy, RHREC, UHS Campus, Bengaluru, Karnataka, India \\ ${ }^{6}$ Department of Biotechnology and Crop Improvement, College of Horticulture, Bengaluru, \\ Karnataka, India \\ *Corresponding author
}

\section{A B S T R A C T}

\begin{tabular}{|l|}
\hline K e y w o r d s \\
$\begin{array}{l}\text { Surinam cherry, } \\
\text { Germination, } \\
\text { Survivability }\end{array}$ \\
\hline Article Info \\
\hline $\begin{array}{l}\text { Accepted: } \\
\text { 06 August } 2018 \\
\text { Available Online: } \\
\text { 10 September } 2018\end{array}$ \\
\hline
\end{tabular}

\section{Introduction}

Surinam cherry (Eugenia uniflora L.) commonly called as pitanga or Brazillian cherry or pumpkin cherry. An underutilized minor fruit crop having its own medicinal value, belongs to family myrtaceae and native of Surinam, South American country and hence it got its name as a surinam cherry. In temperate zones, the plant is grown in pots for its attractive foliage and bright fruits. Pitanga can be used as a live fence and ornamental
Experiment on effect of growth regulators and chemicals on germination of surinam cherry (Eugenia uniflora L.) seeds was carried out in the college of Horticulture Mysuru during the year 2017-18. The experiment was done with completely randomized design having eight treatments with three replications. Among the different treatment seeds which were water soaked over-night $\left(\mathrm{T}_{2}\right)$ took minimum number of days for early germination (18.33 days), complete germination (43.00 days) and fifty per cent germination (25.00 days). $\mathrm{GA}_{3}$ treatment at $500 \mathrm{ppm}\left(\mathrm{T}_{4}\right)$ for 30 minutes showed maximum germination percentage $(100.00 \%)$, survivability percentage $(87.50 \%)$ and vegetative growth parameters like seedling height, number of leaves and seedling girth at 60 and 120 days after transplanting.

plant as it grow slowly; this species has dense and compact leaves. Fruits are rich source of vitamin-C $(26.3 \mathrm{mg} / 100 \mathrm{~g})$ and Vitamin-A i.e., 1200-2000 IU (Santos et al., 2010 and Lira et al., 2007). They are an excellent addition to fruit cups, salads, custard pudding, ice cream and can be made into sauce or preserved whole in syrup. They are often made into jam, jelly, relish or pickles. Brazilians ferment the juice into vinegar or wine and prepare distilled liquor (Ferreira et al., 1987). This species has also attracted the attention of the 
pharmaceutical industry, since fruits are rich in vitamins and antioxidants and also due to properties like antinociceptive, hypothermic effect, antidiabetic and antibacterial effect of leaf extract (Fadeyi and Akpan, 1989).

Surinam cherry is commercially propagated by seeds and vegetative methods like grafting. To undertake propagation by vegetative means, production of healthy and vigorous rootstock is very important. Since the seeds exhibit slow and less germination, pregermination treatments may enhance the germination potential of surinam cherry seeds. Hence the study was carried out to increase the germination potential and survivability of the seedlings with different chemicals and growth regulators.

\section{Materials and Methods}

The present investigation was carried out in college of Horticulture Mysuru during 201718. The experiment was laid out with completely randomized design having eight treatments viz. control $\left(\mathrm{T}_{1}\right)$, water soaking over-night $\left(\mathrm{T}_{2}\right), \mathrm{GA}_{3} 250 \mathrm{ppm}\left(\mathrm{T}_{3}\right), \mathrm{GA}_{3} 500$ ppm $\left(\mathrm{T}_{4}\right)$, thiourea one per cent $\left(\mathrm{T}_{5}\right), \mathrm{KNO}_{3}$ one per cent $\left(\mathrm{T}_{6}\right)$ for 30 minutes, $\mathrm{HCl} 25$ per cent $\left(\mathrm{T}_{7}\right)$ for 5 seconds and seeds soaked in 10 per cent vermiwash over-night $\left(\mathrm{T}_{8}\right)$.

Seeds were sown during last week of October, 2017 in protrays under lab condition. Later 30 days after sowing seedlings were transplanted to polybags of size $5 \times 8$ " filled with potting mixture. Watering was done immediately after transplanting and weeding was done as and when required.

Observation like number of days taken for initiation of germination, complete germination and per cent germination. Seedling growth characters like seedling height, number of leaves and girth of the seedling were recorded.
The data generated from study were subjected to analysis by using standard method suggested by Panse and Sukhatme (1985).

\section{Results and Discussion}

\section{Germination behavior}

Among the different treatments, seeds soaked in water over-night took minimum number of days for initiation of germination, fifty per cent germination and complete germination (18.00, 25.33 and 43.00 days, respectively) while it took maximum number of days for seeds treated with $\mathrm{HCl} 25$ per cent for initiation of germination and complete germination (24.33 and 49.33 days respectively) and seeds treated with vermiwash took maximum (28.33) number of days for fifty per cent germination (Table 1).

Soaking of seeds in water stimulates and produces enzymes like amylase and lipase which activate storage materials in seeds. Rehydration causes early emergence since all pre-germinative processes for germination had already occurred in seed. The other possible fact for better germination per cent by water soaking may be that it stimulates series of biochemical change in the seed that are essential to initiate the emergence process like break down dormancy, hydrolysis, metabolism of growth inhibitors, imbibition and activation of enzymes, as reported by Patil et al., (2018) in jamun. Similar results were coincide with the findings of Pandey and Singh (2000) in guava and Zahang et al., (2015) in litchi.

\section{Per cent germination and survivability}

Per cent germination and survivability per cent were maximum (100.00 and $87.50 \%$, respectively) in seeds treated with $\mathrm{GA}_{3} 500$ ppm and 10 per cent vermiwash. Whereas, it was lowest in seeds treated with $\mathrm{HCl} 25$ per cent i.e., 76.67 and 54.17 per cent, respectively (Table 1). 
The increase in germination percentage with $\mathrm{GA}_{3}$ might be due to the fact that $\mathrm{GA}_{3}$ involved in the activation of cytological enzymes which stimulates $\alpha$-amylase enzyme which convert insoluble starch into soluble sugars or might have antagonized the effect of inhibitors present in seeds thus helps in higher germination(Hartman and Kester, 1997). These results are close conformity with the findings of Kalyani et al., (2014) in guava. Barman et al., (2016) reported that jamun seeds treated with $\mathrm{GA}_{3} 100$ ppm shown maximum percentage of germination. This may be due to $\mathrm{GA}_{3}$ helps in accelerating seed germination, increasing seedling vigour and improving physiological status of the plant. $\mathrm{GA}_{3}$ induces maximum seed germination due to the diffusion of endogenous auxin and gibberellins like substances, as reported by Pawshe et al., (1997) in aonla. Maximum survival percentage was observed in the treatment $\left(\mathrm{T}_{4}\right)$ seeds treated with $\mathrm{GA}_{3} 500$ ppm. This might be due to that quicker root and shoot development and making the seedling stouter, withstanding the transplanting shock and resisting root diseases. The result is conformity with the findings of Palepad et al., (2017) in custard apple, Kumar et al., (1997) in guava and Gurung et al., (2014) in passion fruit.

Table.1 Effect of chemicals and growth regulators on germination characters of Surinam cherry seeds

\begin{tabular}{|c|c|c|c|c|c|}
\hline \multirow[b]{2}{*}{ Treatments } & \multicolumn{3}{|c|}{ Days taken for } & \multirow{2}{*}{$\begin{array}{c}\text { Germination } \\
\text { percentage } \\
(\%)\end{array}$} & \multirow{2}{*}{$\begin{array}{l}\text { Survivability } \\
\text { percentage } \\
(\%)\end{array}$} \\
\hline & $\begin{array}{l}\text { Initiation of } \\
\text { germination }\end{array}$ & $\begin{array}{c}\text { Complete } \\
\text { germination }\end{array}$ & $\begin{array}{l}\text { Fifty per cent } \\
\text { germination }\end{array}$ & & \\
\hline $\mathrm{T}_{1}$ (Control) & 22.00 & 47.67 & 27.30 & $\begin{array}{c}86.67 \\
(68.85) *\end{array}$ & $\begin{array}{c}54.17 \\
(47.41) *\end{array}$ \\
\hline $\begin{array}{l}\mathrm{T}_{2} \text { (Water } \\
\text { soaking) }\end{array}$ & 18.33 & 43.00 & 25.00 & $\begin{array}{c}96.67 \\
(83.46)\end{array}$ & $\begin{array}{c}66.67 \\
(54.83)\end{array}$ \\
\hline $\begin{array}{l}\mathrm{T}_{3}\left(\mathrm{GA}_{3} 250\right. \\
\mathrm{ppm})\end{array}$ & 19.33 & 44.67 & 25.67 & $\begin{array}{c}96.67 \\
(83.46)\end{array}$ & $\begin{array}{c}83.33 \\
(66.20)\end{array}$ \\
\hline $\begin{array}{l}\mathrm{T}_{4}\left(\mathrm{GA}_{3} 500\right. \\
\mathrm{ppm})\end{array}$ & 19.00 & 44.00 & 26.00 & $\begin{array}{l}100.00 \\
(89.41)\end{array}$ & $\begin{array}{c}87.50 \\
(69.20)\end{array}$ \\
\hline $\begin{array}{l}\mathrm{T}_{5} \text { (Thiourea } 1 \\
\% \text { ) }\end{array}$ & 19.33 & 47.33 & 27.67 & $\begin{array}{c}90.00 \\
(71.56)\end{array}$ & $\begin{array}{c}75.00 \\
(60.51)\end{array}$ \\
\hline $\begin{array}{l}\mathrm{T}_{6}\left(\mathrm{KNO}_{3} 1\right. \\
\%)\end{array}$ & 19.67 & 46.00 & 27.67 & $\begin{array}{c}96.67 \\
(83.46)\end{array}$ & $\begin{array}{c}79.17 \\
(63.09)\end{array}$ \\
\hline $\mathrm{T}_{7}(\mathrm{HCl} 25 \%)$ & 24.33 & 49.33 & 26.33 & $\begin{array}{c}76.67 \\
(61.22)\end{array}$ & $\begin{array}{c}54.17 \\
(47.42)\end{array}$ \\
\hline $\begin{array}{l}\mathrm{T}_{8}(\text { Vermiwash } \\
10 \%)\end{array}$ & 20.67 & 45.67 & 28.33 & $\begin{array}{l}100.00 \\
(89.41)\end{array}$ & $\begin{array}{c}87.50 \\
(69.29)\end{array}$ \\
\hline S.Em \pm & 00.35 & 0.44 & 0.58 & 02.63 & 04.17 \\
\hline C.D@ $@$ 5\% & 01.07 & 01.33 & 01.74 & 07.97 & 12.61 \\
\hline
\end{tabular}

* Values in parenthesis are arc sin transformation data 
Table.2 Effect of chemicals and growth regulators on growth parameters of surinam cherry seeds

\begin{tabular}{|c|c|c|c|c|c|c|}
\hline \multirow[t]{2}{*}{ Treatments } & \multicolumn{2}{|c|}{ Seedling height (cm) } & \multicolumn{2}{|c|}{ Number of leaves } & \multicolumn{2}{|c|}{ Seedling girth (mm) } \\
\hline & 60 DAT & 120 DAT & 60 DAT & 120 DAT & 60 DAT & 120 DAT \\
\hline $\mathrm{T}_{1}$ (Control) & 6.67 & 08.87 & 09.40 & 16.47 & 0.92 & 1.27 \\
\hline $\mathrm{T}_{2}$ (Water soaking) & 7.73 & 09.37 & 09.87 & 18.00 & 1.23 & 1.69 \\
\hline $\mathrm{T}_{3}\left(\mathrm{GA}_{3} 250 \mathrm{ppm}\right)$ & 8.19 & 12.02 & 10.73 & 23.67 & 1.27 & 2.07 \\
\hline $\mathrm{T}_{4}\left(\mathrm{GA}_{3} 500 \mathrm{ppm}\right)$ & 8.76 & 13.67 & 12.07 & 24.00 & 1.35 & 2.17 \\
\hline $\mathrm{T}_{5}$ (Thiourea $1 \%$ ) & 6.97 & 10.01 & 09.47 & 15.93 & 1.09 & 1.62 \\
\hline $\mathrm{T}_{6}\left(\mathrm{KNO}_{3} 1 \%\right)$ & 7.09 & 11.02 & 09.60 & 19.27 & 1.11 & 1.58 \\
\hline $\mathrm{T}_{7}(\mathrm{HCl} 25 \%)$ & 6.31 & 07.85 & 08.20 & 13.60 & 0.90 & 1.24 \\
\hline $\mathrm{T}_{8}$ (Vermiwash $\left.10 \%\right)$ & 7.56 & 11.40 & 10.07 & 22.33 & 1.27 & 1.94 \\
\hline S.Em \pm & 0.13 & 00.20 & 00.35 & 00.58 & 0.027 & 0.03 \\
\hline C.D@5\% & 0.38 & 00.60 & 01.07 & 01.75 & 0.085 & 0.11 \\
\hline
\end{tabular}

DAT- Days After Transplanting

\section{Seedling growth parameters}

\section{Seedling height}

Seeds treated with $\mathrm{GA}_{3} 500 \mathrm{ppm}\left(\mathrm{T}_{4}\right)$ showed significantly maximum values for seedling height at 60 and 120 days after transplanting i.e., 8.76 and $13.67 \mathrm{~cm}$, respectively. Whereas, minimum values for the same was noticed in $\mathrm{HCl} 25$ per cent $\left(\mathrm{T}_{7}\right)$ i.e., 6.31 and $7.85 \mathrm{~cm}$, respectively (Table 2). The increased seedling height with $\mathrm{GA}_{3}$ treatment was due to the fact that this hormone increased osmotic uptake of nutrients, causing cell multiplication and cell elongation in the cambium tissue of the internodal region and thus increased height of the plant, as reported by Patil et al., (2018) in jamun. The results are also in accordance with result of Harshavardhan and Rajasekhar (2012) in jackfruit.

\section{Number of leaves}

Seeds treated with $\mathrm{GA}_{3} 500 \mathrm{ppm}\left(\mathrm{T}_{4}\right)$ showed significantly maximum values for number of leaves at 60 and 120 days after transplanting i.e., 12.07 and 24.00, respectively. Whereas, minimum values for the same was noticed in
$\mathrm{HCl} 25$ per cent $\left(\mathrm{T}_{7}\right)$ i.e., 8.20 and 13.60 , respectively (Table 2 ). This might be due to maximum height of seedlings resulted in more number of leaves. This also helps in invigoration of physiological process of plant and stimulatory effect of chemicals to form new leaves at faster rate. Activity of $\mathrm{GA}_{3}$ at the apical meristem resulting in more synthesis of nucleoprotein responsible for increasing leaf initiation and area as reported by Palepad et al., (2017) in custard apple.

It may also due to that $\mathrm{GA}_{3}$ which induced vigorous growth by more number of branches which in turn facilitates better harvest of sunshine by the plants to produce more number of leaves as reported by Patil et al., (2018) in jamun. This is in line with the results of Shaban (2010) in mango and Kadam et al., (2010) in Kagzi lime.

\section{Seedling girth}

Seeds treated with $\mathrm{GA}_{3} 500 \mathrm{ppm}\left(\mathrm{T}_{4}\right)$ showed significantly maximum values for girth of the seedling at 60 and 120 days after transplanting i.e., 1.35 and $2.17 \mathrm{~mm}$, respectively. Whereas, minimum values for the same was noticed in $\mathrm{HCl} 25$ per cent $\left(\mathrm{T}_{7}\right)$ 
i.e., 0.9 and $1.24 \mathrm{~mm}$, respectively (Table 2). This might be due to greater cell division and elongation at the stem portion leads to increased photosynthetic activity, accelerated translocation and efficiency of utilizing photosynthetic products resulting in cell elongation and rapid cell division in growing portion. GA application may be attributed to the cell multiplication and elongation in the cambium tissue in custard apple (Palepad et al., 2017). The results obtained in the present investigation are in close conformity with the results of Kadam et al., (2010) in kagzi lime, Gurung et al., (2014) in passion fruit, Barman et al., (2016) and Patil et al., (2018) in jamun.

Seeds which were water soaked overnight results in early and complete germination, however, germination percentage, survivability percentage and seedling growth parameters were recorded maximum in $\mathrm{GA}_{3}$ treated seeds.

\section{References}

Barman, P., Rekha, A. and Paneerselvan, P., 2016, Effect of different doses of gibberellic acid and benzyl adenine on germination and morpho-physiological characters in jamun (Syzygium cumini Skeels.) under different propagation substrates. J. Farm Sci. 29(1): 140-142.

Fadeyi, M. O. and Akpan, U. E., 1989, Antibacterial activities of the leaf extracts of Eugenia uniflora L. Phytotherpy Res. 3(4): 154-155.

Ferreira, F. R., Ferreira, S. A. N. and Carvalho, J. E. U., 1987, Fruit species unexplored, with economic and social potential for Brazil. J. Fruit Growing. 9: 11-22.

Gurung, N., Swamy, G. S. K., Sarkar, S. K. and Ubale, N. B., 2014, Effect of chemicals and growth regulators on germination, vigour and growth of passion fruit (Passiflora edulis Sims.). Int. Quarterly J. Life Sci. 9(1): 155-157.

Harshavardhan, A. and Rajasekhar, M., 2012, Effect of pre-sowing seed treatments on seedling growth of jackfruit (Artocarpus heterophyllus Lam.). J. Res. ANGRU. 40(4): 87-89.

Hartman, H. T. and Kester, E., 1997, Plant propagation principles and practices. Prentice Hall of India Pvt. Ltd., New Delhi. pp: 130-144.

Kadama, A. B., Singh, D. B. and Kade, R. A., 2010, Effect of plant growth regulators and potassium nitrate on growth of seedling of kagzi lime. Asian J. Hort. 5(2): 431-434.

Kalyani, M., Bharad, S. G. and Parameshwar, P., 2014, Effect of growth regulators on seed germination in guava. Int. J. Biol. Sci. 5(1): 81-91.

Kumar, C. S., Palaniswamy, V., Jayaraj, T. and Arumugam, R., 1997, Studies on certain seed tecnological aspects in guava (Psidium guajava L.). South Indian Hort. 39:315-316.

Lira, J. J. S. D., Bezerra, J. E. F., Lederman, I. E. and Silva J. J. F. D., 2007, Surinam cherry. Recife. Pernambuco Agril. Res. pp: 1-87.

Palepad, K. B., Bharad, S. G. and Bansode, G. S., 2017, Effect of seed treatments on germination, seedling vigour and growth rate of custard apple (Annona squamosa.). J. Pharmaco Phytochem. 6(5): 20-23.

Pandey, D. and Singh, H. P., 2000, Effect of seed pre-treatment on promotion of germination in guava. Ann. Agric. Res. 21: 279-281.

Panse, V. G. and Sukhatme, P. V., 1985, Statistical methods for agricultural workers. ICAR New Delhi. pp: 381.

Patil, H., Tank, R. V., Bennurmath, P. and Patel, M., 2018, Effect of seed treatment on germination and seedling growth of 
jamun (Syzygium cumini). Int. J. Curr. microbiol. Appl. Sci. 7(2): 2654-2659.

Pawshe, Y. H., Patil, N. B. and Patil, L. P., 1997, Effect of pre-germination seed treatment on germination and vigour of seedlings in aonla (Emblica officinalis Garten.). PKV Res. J. 21(2): 152-154.

Santos, A. K. L., Costa, J. G. M., Menzes, I. R. A., Cansancao, I. F., Santos, K. K. A., Matias, E. F. F. and Coutinho, D. M., 2010, Antioxidant activity of five Brazilian plants used as traditional medicines and food in Brazil. Pharmacogn. Mag. 6(24): 335-338.

Shaban, A. E. A., 2010, Improving seed germination and seedling growth of some mango rootstocks. AmericanEuropean J. Agric. and Environ. Sci., 7(5): 535-541.

Zhang, C., Jiefang, W., Danwen, F., Wang, L., Chen, J., Cai, C. and Liangxi, O., 2015, Soaking, temperature, and seed placement affect seed germination and seedling emergence of Litchi chinensis. Hort. Sci. 50(4): 628-63.

\section{How to cite this article:}

Pavithra, S., G.S.K. Swamy, G.J. Suresh, Vishnuvardhana, S.V. Patil and Halesh, G.K. 2018. Effect of Growth Regulators and Chemicals on Germination of Surinam Cherry (Eugenia uniflora L.) Seeds. Int.J.Curr.Microbiol.App.Sci. 7(09): 546-551. doi: https://doi.org/10.20546/ijcmas.2018.709.065 